\title{
The Changing Role of Irrigated Colocasia esculenta (taro) on Nuku Hiva, Marquesas Islands: From an Essential Element of Colonization to an Important Risk-Reduction Strategy
}

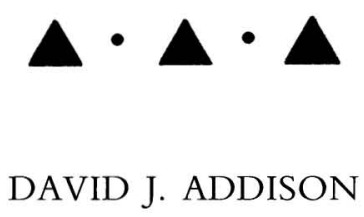

This paper argues that, for some islands in Polynesia, wet cultivation of taro (Colocasia esculenta [L.] Schott) ${ }^{1}$ would have been an important agricultural ${ }^{2}$ strategy on initial colonization. The argument is based on theoretical considerations rather than on archaeological data. The main point is that wet cultivation of taro is the most energy-efficient of the Oceanic agricultural subsystems and was the most economical use of a limited labor pool. An ancillary point is that colonizing populations may have been at some risk of excessive protein intake and wet taro would have been their fastest-producing farinaceous crop. Nuku Hiva Island in the Marquesas Islands serves as an example, and it will be argued that wet taro was likely a crucial crop in the initial stages of island colonization and that, although later eclipsed by breadfruit, it remained important throughout the island's prehistory. I argue that the role of wet taro changed through time from being a quick and efficient caloric source at colonization to being an important riskreduction strategy in later periods. This argument is not only contrary to a Boserupian model of agricultural development (Boserup 1965), but actually suggests an inversion of Boserup's sequence of agricultural stages (also see discussion in Leach 1999). This paper offers an example of modeling based on the specifics of local conditions and accounts for the specific agricultural requirements of different cultigens and agricultural subsystems within particular environmental constraints.

\section{COLONIZATION STRATEGIES: WEST VS. EAST POLYNESIA}

Current archaeological evidence indicates that most of West Polynesia was colonized in a burst of voyaging and discovery $\sim 3000-2700$ years ago (Anderson and 
Clark 1999; Burley and Dickinson 2001; Burley et al. 1999; Kirch 1997; Petchey 2001; Sand 2000, 2003). Known collectively as the Lapita culture, these populations colonized islands as far east as Samoa (Fig. 1). Colonization of islands farther east then stopped for at least a millennium (see discussion in Anderson 2003).

One of the fundamental differences in the colonization of West Polynesia and East Polynesia is that, in West Polynesia, the islands are rarely more than a threeday sail apart (Irwin 1992). This means that colonizers of new islands had an easily accessible support network to rely on if they needed it. Such a support network would mean that colonists had access to emergency food, but beyond this mere caloric aspect, colonists of new islands would have been able to maintain frequent contact with a wider social network (see also Best 2002; Irwin 1998, 2000).

This is not the case in East Polynesia where island groups are a week or even several weeks' sail apart (Irwin 1992). Colonists to East Polynesia would have had to have been much more self-reliant for food; they also would have been largely cut off from the social network they had left. This latter aspect may likely be the reason why there is a different temporal pattern in the colonization in the two regions of Polynesia (see Anderson 2003 for ideas on technological and climatic reasons).

\section{OCEANIC CULTIGENS AND AGRICULTURAL SUBSYSTEMS}

This section is drawn from previous work describing Oceanic agriculture (e.g., Ayres and Haun 1990; Barrau 1958, 1961, 1965; Kirch 1994; Spriggs 1981, 1984, 1990; Yen 1973a, 1973b, 1990, 1993). The colonizing population of Nuku Hiva likely brought with them most of the traditional Oceanic cultigens or acquired them from their home islands soon after settlement. The main carbohydrateproducing crops were breadfruit (Artocarpus altilis [Parkinson] Fosberg), bananas (Musa spp.), yam (Dioscorea alata L.), and aroids (Colocasia esculenta and Alocasia macrorrhizos [L.] G. Don). These colonists would have been coming from a culture that had at least a millennium of experience cultivating these species on Oceanic islands. The colonists would have had detailed knowledge of the agricultural requirements of the cultigens they carried with them as well as carrying mental templates for a developed set of agricultural subsystems (Yen 1990). These agricultural subsystems can be broadly categorized into swiddens, multistory gardens, and water-controlled taro cultivation.

Swidden is a agricultural subsystem in which vegetation is cleared, with or without fire, cultigens are harvested for 1-3 production cycles (roughly equated to years), and then the plot is abandoned for 5-20 years of fallow.

Multistory gardens are vertically stratified and are relatively permanent. These are subsystems in which a cleared plot is initially planted with a tree crop and at least one other (usually herbaceous) cultigen, each having different growth habits and different production schedules. A common combination is breadfruit and aroids, with perhaps banana or another intermediate-sized cultigen. The crops are harvested in succession as they produce, with the herbaceous component replanted periodically. For example, in a plot planted in breadfruit, taro, and banana, the taro could be harvested within 12 months of planting, the bananas within 24 months, and the breadfruit within 5 years. The breadfruit overstory in 


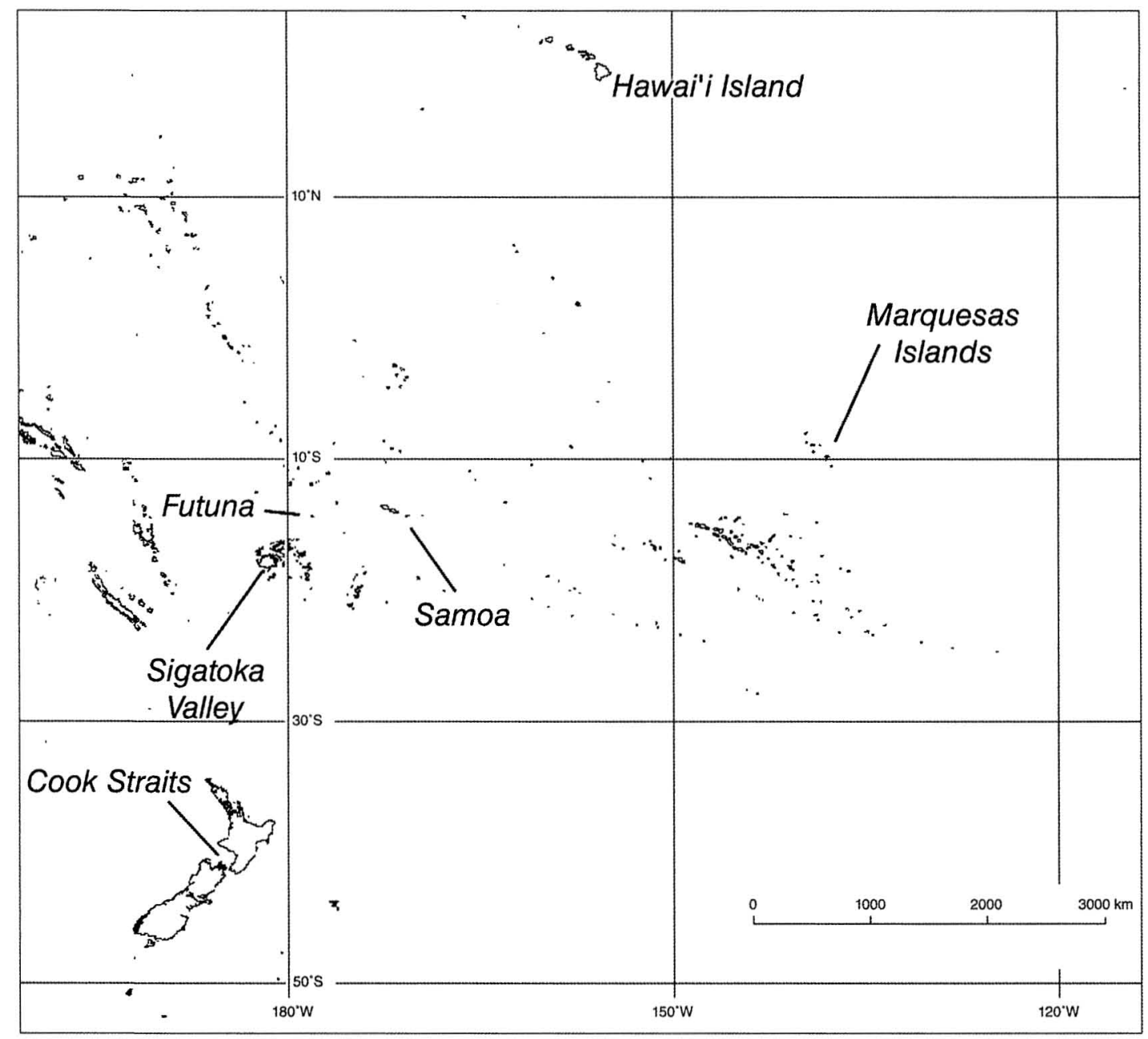

Fig. 1. Oceania showing location of the Marquesas Islands and places mentioned in the text. Base map courtesy of Peter Minton (http://www.evs-islands.com). 
this example would continue in production for many decades; as soil fertility allowed, the herbaceous lower stories would be replanted many times.

Water-controlled taro cultivation has three distinct forms. Although each form could be considered irrigation, the term irrigation is used here to indicate only situations where flowing water is directed onto cultivated surfaces. In Polynesia this takes the form of pondfields. These are planting plots with artificially leveled surfaces usually arranged as a series of "stair-step" terraces. Water is directed onto the uppermost terrace from whence it flows in succession to the lower terraces. The terraces are arranged so that the water "ponds" or forms a layer (at least several centimeters deep) on the surface of each terrace. Because pondfield irrigation systems are gravity-fed, their construction requires land with some slope. A second form of water control is raised-bed cultivation. This technique is utilized in relatively flat areas with a high water table or with standing surface water. Trenches are dug (usually in a rectilinear pattern) with excavated material piled on the spaces between trenches, thus creating raised beds whose surface is used for planting taro. Water flows in the trenches around the beds. Atoll pit cultivation is a third form of water control in which pits are dug to access the thin Ghyben-Herzberg lens of fresh water. The bottoms of the pits where taro is planted are enriched with organic matter in the form of leaf litter.

\section{MARQUESAN AGRICULTURE AT EUROPEAN CONTACT}

When Europeans arrived in the Marquesas Islands in the late eighteenth century, they found islands heavily reliant on breadfruit grown in multistory gardens, with other crops and agricultural subsystems assuming secondary roles (see Addison 2006 for a full discussion of contact-period Marquesan agriculture). Huge amounts of breadfruit were preserved in pit silos as pickled paste (termed $m \bar{a}$ in Marquesan). Yen (1990) has suggested that the cultivation systems and cultigens that island colonists bring with them go through a process of reassortment in each new island environment. In the colonization of Nuku Hiva, the first step in this process would have been wresting adequate agricultural carbohydrates from the island's pristine environment. The following sections suggest how this may have been accomplished and how the subsequent evolution of Marquesan agricultural systems led to the configuration encountered by the European explorers.

\section{THE PRISTINE COLONIZATION ENVIRONMENT OF NUKU HIVA}

The Marquesas Islands are located in the eastern Pacific just south of the equator (Fig. 2). Nuku Hiva, at $339.5 \mathrm{~km}^{2}$, is one of the two largest islands in the group and reaches an elevation of $1224 \mathrm{~m}$. A shield volcano built the island some 4.3 million years ago, with additional volcanic activity about 2.9 million years ago adding complexity to the island's geology. Subsequent erosion has left Nuku Hiva with a dramatically dissected landscape (Fig. 3). The volcanic relief of interlocking calderas and plateaus that dominates to the west and in the middle of the island grows in complexity to the north and east where secondary ridges form promontories between amphitheater-shaped valleys at the head of often-deep bays. Between bays, segments of rocky coast-mostly dominated by cliffs- 


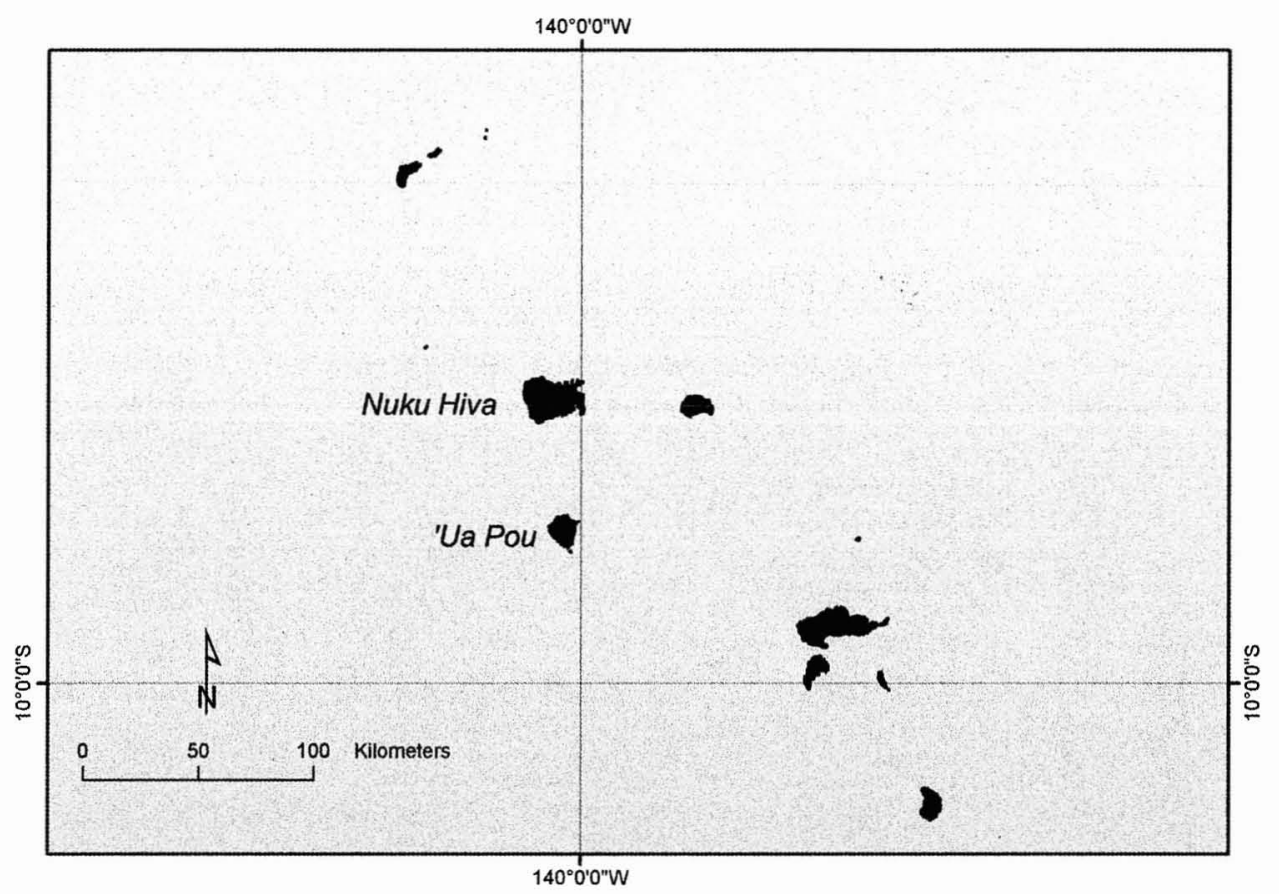

Fig. 2. Marquesas Islands.

encircle the island. In the interior, extreme slopes are a regular feature of the inner and outer edges of the calderas as well as the secondary ridges dividing valleys. Most habitable areas are located in the valley floors or on adjacent slopes. Several valleys have streams that maintain flow even during drought. Coral growth is generally confined to small isolated patches, but there are a few small fringing reefs in protected bays.

Cauchard and Inchauspe (1978) summarized the dominant characteristics of the Marquesan climate as follows: slight variation in temperature throughout the year with daytime temperature at sea level always above $25^{\circ} \mathrm{C}$; rarity of stormy weather and absence of hurricanes; stable easterly winds; little seasonality; and great temporal variability in precipitation with extended periods of drought. Mean annual rainfall at Hatihe'u Valley on Nuku Hiva is $1577 \mathrm{~mm}$ but can vary from $<1000 \mathrm{~mm}$ to $>2000 \mathrm{~mm}$ (see Addison 2006 for a detailed discussion of rainfall patterns on Nuku Hiva).

More than 1000 years of Polynesian use and 200 years of feral ungulates has radically transformed the modern Marquesan vegetation from its pre-human configuration (Decker 1970, 1992). Although any description of the colonizationperiod vegetation of Nuku Hiva is necessarily speculative, some ideas can be suggested from small areas of remnant native vegetation. Well-watered valley floors and lower slopes (areas that would have been attractive for establishing agriculture) may have had vegetation associations similar to those described by Florence and Lorence (1997:232-233): 


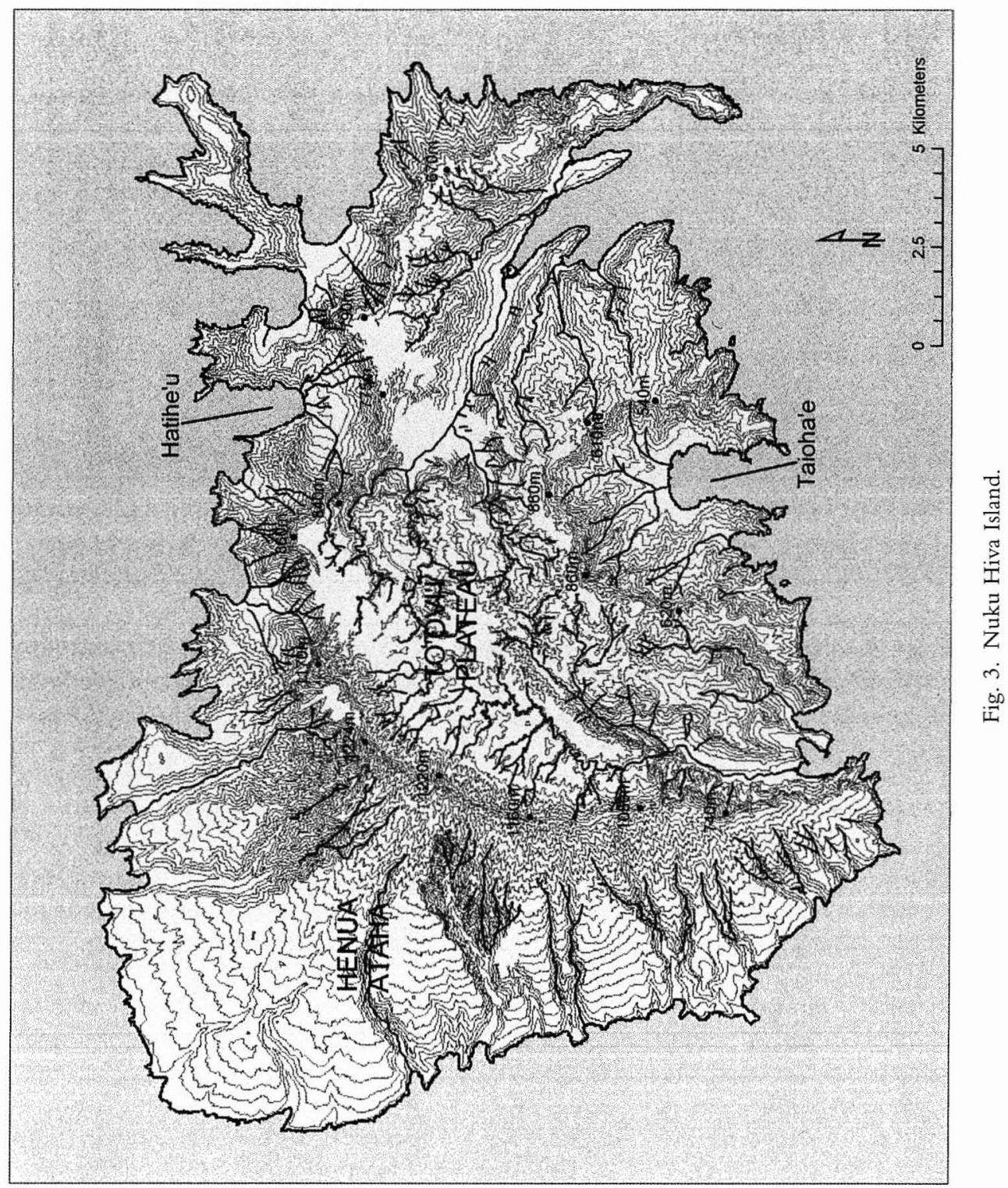


Relicts of a transitional forest type occur in certain areas from just above sea level to about 200 or $300 \mathrm{~m}$ elevation where the annual precipitation is less than $2000 \mathrm{~mm}$. Here Pisonia grandis $\mathrm{R}$. Br. is the dominant tree species, reaching $15 \mathrm{~m}$ tall with large, radiating surface roots. Other canopy trees attaining an impressive size include Thespesia populnea (L.) Sol. ex Corrêa, Calophyllum inophyllum L., and Terminalia glabrata J. R. \& G. Forst. The understory consists of the shrubs Eugenia reinwardtiana (Blume) DC., Psydrax odorata (G. Forst.) A. C. Sm. \& S. P. Darwin, and Maytenus crenatus (G. Forst.) Lobr.-Callen as well as herbaceous species....

Low- to mid-elevation moist and wet forest communities occur between ca. 300 and $800 \mathrm{~m}$ elevation in areas with an annual precipitation of $2000-3000 \mathrm{~mm}$, usually on relatively wet windward slopes and crests where less disturbance has occurred. These forests may reach, but rarely exceed, $20 \mathrm{~m}$ in height.

Several different native associations occur in these zones. Hibiscus tiliaceus forest with an understory of Angiopteris evecta (G. Forst.) Hoffm. is perhaps the commonest, often in association with Pandanus tectorius Sol. ex Parkinson....

A mixed forest of Hibiscus tiliaceus, Pandanus tectorius, and Weinmannia parviflora var. marquesana occurs in the upper parts of Taipivai valley. This association is transitional between the Hibiscus-Angiopteris forest and upper elevation forests because, in addition to the former two taxa, it also includes Weinmannia and Crossostylis biflora J. R. \& G. Forst., which are characteristic of the wet forest.

Although now confined to limited areas above $300 \mathrm{~m}$ elevation, in the colonization period the low- to mid-elevation moist and wet forest vegetation associations likely extended much lower into valleys, merging with the littoral zone vegetation in the well-watered valleys (Lorence pers. comm.). Such vegetation would have been difficult to clear with stone tools and impervious to fire except during extreme droughts.

\section{AZOTEMIA AND HIGH-PROTEIN DIETS}

Before considering the colonization of Nuku Hiva, it will be helpful to review some facts about human nutritional requirements. Protein, fat, and carbohydrate are essential macronutrients for humans. Each can be metabolized for energy, however no more than 35-40 percent of calories can come from protein (Cordain et al. 2000) or there is a buildup of nitrogenous compounds in the blood (azotemia). Speth (1991a) points out that excessive protein intake "may exceed the rate at which the liver can metabolise amino acids, and the body can synthesise and excrete urea, leading to serious impairment of liver and kidney function and a variety of other disorders, and ultimately death" (see also Noli and Avery 1988; Speth 1989, 1991b; Speth and Spielmann 1983). Pregnant women may be able to tolerate only half as much protein (see discussion in Rush 1989 and sources therein), an important constraint on a colonizing population with a limited number of fecund women. So, to avoid azotemia, people must get at least 60 percent and as much as 80 percent (pregnant women) of their calories from fat or carbohydrates.

\section{WET TARO AND THE INITIAL COLONIZATION OF NUKU HIVA}

A canoe (or several canoes) of colonists arriving on Nuku Hiva would have found a pristine environment providing an abundance of avian and marine protein, but one that may have been lacking in non-protein calories. The natural environment 
of these pristine islands would have provided almost no human-digestible carbohydrates. The colonists would have been lacking the carbohydrate calories of their former customary diet, which would be essential for survival in the absence of adequate supplies of fat. Davidson and Leach (2001) have proposed a similar situation for the Cook Straits area of New Zealand (see also Leach 2006 for a wider discussion of fat-deprivation in the Pacific). Fat from marine mammals, certain avifauna, and turtles may have provided enough non-protein calories to sustain the population initially, but it is unclear how long it would have taken to deplete the easily available high-fat resources. ${ }^{3}$ The fact that these resources disappear immediately after colonization in Marquesan archaeological sites may indicate their rapid decline due to human predation (Kirch 1973; Rolett 1998; Sweeny et al. 1993). To the extent that Nuku Hiva's wild fat resources were susceptible to rapid depletion, it would have been crucial for colonists' survival to secure a carbohydrate source through agriculture as soon as possible to avoid the deleterious effects of azotemia.

I make several assumptions about the colonizing population on Nuku Hiva: they were thoroughly agricultural; they were intimately familiar with their cultigens (i.e., they understood each cultigen's productive potential, growing requirements, seasonality or production schedule, etc.); that their culture had at least 1000 years of experience gardening on Oceanic islands and had developed all the major agricultural subsystems; that they had a well-developed resource (both human and natural) management capacity (the very act of organizing voyages to East Polynesia demonstrates such management skills); and that these colonists were capable of evaluating options and making sound cost-benefit decisions.

We can imagine that establishing gardens would have been an immediate priority - first to maintain precious planting stock that had been carefully tended and protected on the voyage and then to establish plantings of adequate size to furnish the small population's carbohydrate needs. This would have been a daunting task given the virgin vegetation the colonists would have faced. The parts of Nuku Hiva with adequate rainfall for agriculture would have been covered to water's edge with primary lowland tropical rainforest. This forest would have been composed of large trees with undergrowth. It would have been hard to burn and difficult to clear.

How would a colonizing population - with a minimal labor force and a small amount of planting stock-maximize their short-term carbohydrate returns? Let us examine the main carbohydrate-producing cultigens and how each would fare. Breadfruit takes several years to first production and then is slow at reproducing-an unlikely candidate for quick carbohydrate returns. Banana starts are large and delicate and it is unlikely that many were transported in limited canoe space over long distances. It would have taken years to build up enough planting stock to provide many carbohydrate calories from these cultigens. Bananas also take a relatively large space and have among the lowest calorie-to-area-planted ratio of Oceanic cultigens (Table 1). Even once enough planting stock had been grown, to a population faced with a landscape covered in primary forest, clearing enough land to satisfy its carbohydrate requirements from banana must have seemed a daunting task. ${ }^{4}$

Dioscorea cultigens have several advantages in the colonization context. A large amount of planting stock can be transported relatively easily over long distances; 
Table i. Yield of Some Oceanic Cultigens under Traditional Cultivation REgIMES

\begin{tabular}{lc}
\hline & METRIC \\
\hline BONS/HECTARE/YEAR \\
\hline Banana & $3-8.8$ \\
Dioscorea & 1.2 \\
Colocasia (swidden) & 5 \\
Colocasia (wet) & 10 \\
\hline
\end{tabular}

Source: data from various sources cited in Kirch 1994:92.

the tubers are not in an active growth state, are resistant to desiccation, and would need to have been protected mainly from salt damage. Each tuber can be cut up to produce many sets, each of which grows into a plant that can be harvested in as little as 7-9 months. The disadvantage of Dioscorea cultigens is that they can take a good deal of ground preparation and have relatively low yield per area (Table 1). Again, the labor involved in clearing and ground preparation of an adequate area may have limited the potential of these cultigens for rapid short-term fulfillment of the community's carbohydrate needs.

Sweet potato (Ipomoea batatas [L.] Lam.) is perhaps the ideal Oceanic cultigen for short-term returns. Some cultivars can be harvested in as little as 4 months and the yield per area is high. However, it is unlikely that this New World cultigen had been introduced to Oceanic agricultural systems before the settlement of the Marquesas.

It is likely that the first settlers in the Marquesas relied on taro to quickly supply the bulk of their carbohydrate needs. As with Dioscorea, large amounts of taro planting stock could have been easily transported; if kept moist and protected from salt, baskets containing hundreds of taro cuttings (the top centimeter of the corm with the attached petiole bases enclosing the apical meristem) could have been transported at sea for a month or more with little difficulty. Moreover, wet cultivation would have given them the best return for their labor.

Swidden-grown taro produces at about $10 \mathrm{t} /$ ha/year. $^{5}$ Once again, clearing enough primary forest to meet the community's carbohydrate requirements would have required considerable labor. Additional clearing would be continually needed as initial swidden fertility was exhausted. By contrast, wet taro provides 2-6 times the carbohydrates (25.1-58.1 t/ha/year) per area of land. An additional benefit is that fallow time is greatly reduced under wet production. So, for clearing the same size piece of land the Marquesan settlers would have had dramatically more food, reduced fallow length, as well as a food supply that was sheltered from the effects of drought. The infrastructure needed for growing irrigated taro (pondfields and canals) need not have taken excessive amounts of labor. In fact, labor inputs for pondfield construction roughly equal those for swidden cultivation (Kirch 1994:161). Additionally, the first pondfields would have been built in the most labor-efficient locations - areas with minimal topography, rich alluvium, and the easiest access to water. In fact, riparian wetlands, in addition to naturally providing the hydric edaphic conditions necessary for wet taro cultivation, may have been one of the few open areas in the forest canopy of colonization- 
period Nuku Hiva. It is likely that these would have been the initial areas used, with raised-bed cultivation. On Nuku Hiva's steep topography, such areas would have been very limited. Cultivation would have rapidly included adjacent sloping ground and utilized pondfields.

The issues relating to cultivation and transport of oceanic crops outlined above have implications for Marquesan prehistory, and for the prehistory of other parts of East Polynesia. Foremost is the issue of crop and population establishment during colonization. Although it has been argued that linguistic evidence suggests relatively independent and relatively late development of pondfields in Polynesia (Kirch and Lepofsky 1993), there are sound agricultural reasons why it may have been the best economic option from initial colonization (see also Spriggs 2002:84). One possible explanation for the linguistic pattern is that East Polynesia's original colonists came from a place like Manu'a or Tutuila in Samoa where raised-bed taro cultivation existed, but where there were not pondfield systems (an atoll origin would also work for this scenario). In a place like Nuku Hiva with limited natural wetlands, pondfields could have been easily conceptualized and developed quickly on the sloping land around wetlands.

Contrary to the common idea that irrigation represents a later phase of agricultural intensification, on high Oceanic islands with conditions similar to Nuku Hiva's, raised-bed and pondfield cultivation were likely among the first techniques to be used. The first Marquesan settlers may have almost immediately established wet cultivation to ensure a quick and reliable supply of carbohydrates with minimum input from their limited labor resources.

The establishment of irrigated crops at the outset suggests a secondary progression of other crops. For example, they must have soon established limited vertically stratified gardens in which to nurture planting stock of their other cultigens (multistory gardens would have been a more efficient use of cleared land than swiddens). Thus, the two main agricultural subsystems of the European-contactperiod Marquesas were likely established almost immediately at initial settlement. The next section deals with the further development of the Marquesan agricultural system through the post-colonization phase to the European-contact period.

\section{LONG-TERM DEVELOPMENT OF THE NUKU HIVA AGRICULTURAL SYSTEM}

In this model of Marquesan prehistory, I argue that it is unlikely that environmental perturbations-especially the droughts that are such an unpredictable aspect of the Marquesan environment - would have seriously impacted the agricultural production of the first Marquesan settlers. They would likely have placed their initial gardens and wet cultivations in the most desirable locations, environments similar to ones on their home islands that were known to be the most stable and productive.

Throughout the initial decades of settlement, patterns of weather would have been observed and people would have noted the periodic droughts of the Marquesas. It is likely that agriculture continued to be a mix of raised beds and pondfields placed in the most desirable locations and, as labor became available through population growth, increasing area planted in vertically stratified gardens. Because of its efficient return of calories for labor, taro probably dominated the diet, with other cultigens adding variety. In breadfruit bumper-crop years, people 
may have preserved some of the excess production as pickled paste $(m \bar{a})$ in small pit silos.

At some point, populations would have become dense enough that pondfields located in the most ideal microenvironments could no longer provide the bulk of carbohydrates (perhaps at least a century after colonization). Maximal pondfield area in a locality was probably determined by minimum stream flow. Because many Nuku Hiva streams are fed by stable aquifers (Addison 2006), pondfield production was probably not seriously impacted by drought. When a population and its pondfield production were balanced, drought would have had little effect beyond reducing dietary variety. However, once a population's size exceeded the production of its pondfields, the first drought would have impacted the multistory gardens and caused some hunger.

Temporal heterogeneity in agricultural production was a certainty in the drought-prone environment of the Marquesas for all agricultural subsystems except pondfields. Risk can be defined in terms of such production shortfalls (Cashdan 1990a:2-3). Modelings suggest that high payoffs in high variance conditions will favor risk-reducing behaviors (Krebs and Kacelnik 1991). The temporal variability in rainfall in the Marquesas fits the high-variance condition of this model and the ability to survive a famine is a high payoff. As populations (and consequent pressure on food resources) increased, payoffs to those practicing riskreduction would have increased. Production of taro in irrigated pondfields is one risk-reduction strategy. When pondfields reached the maximum size allowed by minimum stream flow, storage of breadfruit in pit silos as $m \bar{a}$ would have been an obvious risk-reduction strategy to expand. After the first experiences with drought-induced food shortages, people would have planted more breadfruit trees with the intent of storing it as $m \bar{a}$ to ensure adequate food reserves during future droughts.

The need for increased food supplies would have paralleled increases in population size. The drought-prone Marquesan climate and increasing population size would have put strong selective pressure on risk-reducing behaviors such as pondfield cultivation and $m \bar{a}$ storage. During this stage, vertically stratified gardens would have expanded to their environmental limits, resulting in the emphasis on breadfruit observed at European contact. Alocasia macrorrhizos, Dioscorea cultigens, and $t i$ (Cordyline fruticosa [L.] A. Chev.) would have been particularly desirable in these gardens because each grows for years-continually increasing the size of the edible portion yet not requiring harvest or replanting to maintain edibility. This "field storage" would have further reduced the risk of famine during drought.

It would have now been economical to construct pondfields in less than ideal locations-locations with steeper topography, less rich edaphic media, areas requiring more complex canalization (excavation of pondfields on Nuku Hiva suggest such a scenario; Addison 2006). With the best food-to-labor-input agricultural subsystems maximized, swiddens would have become an economically viable option. A maximum amount of breadfruit may have been reserved for $m \bar{a}$ making and people may have increasingly eaten from their swiddens to the extent possible. People without access to the valuable risk-reducing pondfields or stored $m \bar{a}$ would have had swiddens as their only option.

Within the context of the potentially catastrophic unpredictability of Marque- 
san rainfall, once populations had reached a level that exceeded the food available during droughts, acquisition of food produced by others would have been an increasingly viable option. Models in evolutionary ecology suggest that spatial and temporal aspects of resource availability affect the selective advantage of aggression (Cashdan 1990b). Density and predictability are important factors in assessing the defensibility of a resource. Modeling by Dyson-Hudson and Smith (1978) suggests that when resources are both dense and predictable, territoriality is the adaptive behavioral variant. Pondfields fed by reliable aquifers are among the most dense and predictable of agricultural resources. The placement of Nuku Hiva houses directly adjacent to pondfields indicates that the irrigated taro resource was tightly controlled and highly defensible (Addison 2006). Research by Field $(2002$, 2004a, 2004b) in Fiji indicates territoriality and defensibility of pondfield resources in Sigatoka Valley, suggesting that similar selective forces pertained.

During periods of normal rainfall, there may have been little need to guard pondfields. Aggressive appropriation may not have been an adaptive variant. However, during famine periods, having this resource close at hand would have increased individuals' ability to effectively defend it against such aggressive appropriation. Placing houses near pondfields was likely a behavioral variant that increased fitness by decreasing the chances that the periodically critical pondfield resources were appropriated by others.

$M \bar{a}$ pit silos on Nuku Hiva are also located near houses (and often in the Marquesas their location was camouflaged), suggesting that this highly dense and predictable resource was also subject to aggressive procurement. The whole system of Marquesan settlement and land use may, in fact, have been patterned by aggression and resource defense. Houses were not aggregated, but were dispersed among gardens. Some of the historic sources specifically refer to each plot of land having a house with guardian (Addison 2006). Traditional Marquesan society, as seen through eighteenth- and nineteenth-century European eyes, was violent and aggressive. Land tenure was among the most individualized in pre-European Polynesia. The historic sources repeatedly describe personal and group aggression as dispossessing competitors of the means of food production (Dening 1980; Kirch 1991). In traditional agricultural societies dependent for caloric intake on highly co-evolved cultigens - such as those of the Marquesas Islands - the degree of violent aggression may be among the most heavily selective variables in the social-biological environment.

Kirch (1988), has argued that the emergence of an aggressive and expansive West Hawai'i Island chiefdom may be linked to that region's environmental unpredictability. The Alo chiefdom on Futuna appears to represent a similar situation (Kirch 1994). It is interesting to note two possible parallel examples from the Marquesas. Taioha'e - the driest of the large valleys on Nuku Hiva (Fig. 3) came under the rule of one chief near the time of European contact and was regularly in conflict with other Nuku Hiva valleys until French colonization. At the time of European contact, the entire island of 'Ua Pou (Fig. 2) was ruled by a chiefly line from the dry northeastern side of that island.

In the Marquesas, the final stage of development of agricultural production systems prior to European contact had a heavy emphasis on vertically stratified gardens dominated by breadfruit. Huge amounts of breadfruit were preserved as $m \bar{a}$ 
to reduce famine during drought. Pondfields were also used as a critical faminebuffering mechanism, were built to the hydrological limits of each valley (and perhaps slightly beyond), and were guarded by houses placed directly adjacent to them. Swiddens were a third component of the carbohydrate production system.

\section{CONCLUSION}

This paper has argued that, for colonization-period Nuku Hiva, wet cultivation of taro was the most economical choice for producing maximum carbohydrates with minimal labor. The same argument could be extended to islands with similar environments. Irrigation remained an important aspect of Nuku Hiva production systems as a risk-reduction strategy, but was eventually eclipsed by breadfruit because of the latter's suitability in the Marquesan environment for producing large amounts of storable surplus. Swiddens are argued to have become important only as pondfields and multistory gardens were expanded to their limits.

In Oceania, irrigation is often mistakenly seen to represent the "peaks of intensification" (Spriggs 1990:174). Leach (1999), too, suggests that Pacific agricultural trajectories may not always proceed in a lineal sequence starting with long-fallow swiddening and progressing to more intensive forms of cultivation. She raises the possibility of envisioning a sequence in which reliance on swidden is not the beginning stage. Melinda Allen has recently argued that agricultural change models are "overly focused on productive increases" and that risk-management strategies can be "critical to long-term survival of agronomic systems" (Allen 2004:196). Spriggs (1981:177) notes that the advantages of pondfields over dryland cropping systems include greater control over environmental factors and higher yield/ha than dry land crops grown in equivalent soils. Jane Allen (1987:229, 251-252) provides an empirical example of pondfields preceding swidden, reporting at least 1000 years of pondfield cultivation at Luluku (Hawai'i) before the initiation of swidden cultivation in the area. Hunter-Anderson proposes a non-Boserupian sequence for Yap (1983).

Finding archaeological evidence for the sequence of agricultural development proposed in this paper will be challenging. The earliest use of natural wetlands for raised-bed cultivation is unlikely to have left any archaeological signature. Early pondfield systems are likely to have been small, but they would have been built in the easiest areas-areas that have probably seen relatively constant use since initial colonization. This subsequent use will have obscured most traces of the earliest pondfields. Unlike pondfields, swidden and multistory gardens do not require infrastructural modification of the landscape. Their use is inferred from other data such as the presence of charcoal flecking in stratigraphy, or increases in sedimentation (in the case of swiddens). However, these kinds of evidence often suffer from problems of equifinality. But perhaps the first step in finding evidence of early irrigation is in accepting the possibility of its existence; archaeologists can then design research specifically to address the question.

\section{ACKNOWLEDGMENTS}

Thanks to Geoff Irwin for inviting me to the Island Colonization session at the Manila IPPA and to Sue and Atholl for coordinating this issue of AP. Participants at 
the conference gave me valuable feedback (special thanks to colleagues at the back of the bus on our marathon trip around Luzon-they tolerated endless hours of rambling on this topic). Thanks to Melinda Allen, Janet Davidson, Julie Field, Jean Kennedy, Helen Leach, Mark Merlin, Matthew Spriggs, and anonymous reviewers for providing useful comments on drafts of this paper. Errors in logic, fact, and style remain stubbornly mine.

\section{NOTES}

1. Except for the quote from Florence and Lorence (1997), Latin binomials and botanical attributions follow taxonomic designations at Germplasm Resources Information Network (GRINhttp://www.ars-grin.gov).

2. I use "agriculture" as meaning simply "cultivation of plants" and eschew any value judgments or terminological implications about evolutionary schemes or debates on the origins of agriculture (e.g., as discussed in Leach 1997).

3. Husbandry of swine would have eventually provided fat calories as well. Although able to digest more of the native carbohydrate sources, swine would have faced many of the same challenges as human colonists and it is likely that it would have been some time before their numbers reached levels allowing them to become a significant source of fat calories. Also see Kirch's (2000) discussion of swine and humans competing for limited insular resources.

4. Removing a strip of bark from the circumference of a tree-or girdling-is an effective way of killing many species. In tropical forests where relatively few large trees form a dense canopy with little undergrowth, girdling is efficient at clearing land for agriculture, but must be done a year or two in advance of planting. Experiments estimate that steel tools are 2-4 times more efficient than stone tools for clearing such forests (see discussion in Spriggs 1981: Appendix 4). However, it is unlikely that such forests existed in the Marquesas. The vegetation described above for Nuku Hiva would have been challenging to clear with stone tools and limited labor.

5. Metric tons per hectare per year.

\section{REFERENCES CITED}

Addison, D. J.

2006 Feast or famine? Predictability, drought, density, and irrigation: The archaeology of agriculture in Marquesas Islands valleys. Ph.D. diss. University of Hawai'i.

Allen, J.

1987 Five upland 'ili: Archaeological and historical investigations in the Kane'ohe interchange, interstate highway H-3, Island of Oahu. Honolulu: Bishop Museum.

ALLEN, M. S

2004 Bet-hedging strategies, agricultural change, and unpredictable environments: Historical development of dryland agriculture in Kona, Hawai'i. Journal of Anthropological Archaeology 23:196-224.

Anderson, A.

2003 Initial human dispersal in Remote Oceania: Pattern and explanation, in Pacific archaeology: Assessments and prospects: 71-84, ed. C. Sand. Nouméa: Les cahiers de l'archéologie en Nouvelle-Calédonie 15.

Anderson, A. J., and G. R. Clark

1999 The age of Lapita settlement in Fiji. Archaeology in Oceania 34:31-39.

Ayres, W. S., AND A. E. Haun

1990 Prehistoric food production in Micronesia, in Pacific production systems: Approaches to economic prehistory: 211-227, ed. D. E. Yen and J.M.J. Mummery. Canberra: Department of Prehistory, Research School of Pacific Studies, Australian National University.

BARRAU, J.

1958 Subsistence agriculture in Melancsia. Honolulu: Bishop Museum Press.

1961 Subsistence agriculture in Polynesia and Micronesia. Honolulu: Bishop Museum Press.

1965 L'humide et le sec: An essay on ethnobiological adaptation to contrastive environments in the Indo-Pacific area. Journal of the Polynesian Society 74:329-346. 
BEST, S.

2002 Lapita: A view from the East. Auckland: New Zealand Archaeological Association.

Boserup, E.

1965 The conditions of agricultural grouth: The economics of agrarian change under population pressure. Chicago: Aldine.

Burley, D. V., And W. R. Dickinson

2001 Origin and significance of a founding settlement in Polynesia. Proceedings of the National Academy of Sciences 98(20): 11829-11831.

Burley, D. V., E. Nelson, and R. Shutler Jr

1999 A radiocarbon chronology for the Eastern Lapita frontier in Tonga. Archaeology in Oceania $34: 59-72$.

Cashdan, E.

$1990 a$ Introduction. In E. Cashdan (ed.) Risk and uncertainty in tribal and peasant economies. Boulder, CO: Westview Press, pp. 1-16.

Cashdan, E., ED.

$1990 \mathrm{~b}$ Risk and uncertainty in tribal and peasant economies. Boulder, CO: Westview Press.

Cauchard, G., and J. Inchauspe

1978 Climatologie de l'archipel des Marquises. Cahiers du Pacifique 21 :75-106.

Cordain, L., J. B. Miller, S. B. Eaton, N. Mann, S. H. Holt, and J. D. Speth

2000 Plant-animal subsistence ratios and macronutrient energy estimations in worldwide hunter-gatherer diets. American Journal of Clinical Nutrition 71:682-692.

Davidson, J. M., AND F. LeAch

2001 The Strandlooper concept and economic naivety, in The archaeology of the Lapita dispersal in Oceania: Papers from the Fourth Lapita Conference, June 2000, Canberra Australia: 115123, ed. G. R. Clark, A. J. Anderson, and T. V. Vunidilo. Terra Australis 17. Canberra: Pandanus Books.

DECKER, B. G.

1970 Plants, man, and landscape in Marquesan valleys, French Polynesia. Ph.D. diss. University of California, Berkeley.

1992 Secondary plant cover on upland slopes, Marquesas Islands, French Polynesia. Atoll Research Bulletin 363 (May).

Dening, G.

1980 Islands and beaches: Discourse on a silent land: Marquesas, 1774-1880. Honolulu: University of Hawai'i Press.

Dyson-Hudson, R., And E. A. Smith

1978 Human territoriality: An ecological reassessment. American Anthropologist 80:21-41.

FIELD, J. S.

2002 GIS-based analyses of agricultural production and habitation in the Sigatoka Valley, Fiji, in Pacific landscapes: Archacological approaches: 97-124, ed. T. N. Ladefoged and M. W. Graves. Los Osos: Easter Island Foundation.

2004a Environmental and climatic considerations: A hypothesis for conflict and the emergence of social complexity in Fijian prehistory. Anthropological Archaeology 23:79-99.

$2004 b$ The evolution of competition and cooperation in Fijian prehistory: Archaeological research in the Sigatoka Valley. Ph.D. diss. University of Hawai'i, Manoa.

Florence, J., And D. H. Lorence

1997 Introduction to the flora and vegetation of the Marquesas Islands. Allertonia 7(4):226237.

Hunter-Anderson, R. L.

1983 Yapese settlement patterns: An ethnoarchaeological approach. Agana, Guam: Pacific Studies Institute.

IRWIN, G.

1992 The prehistoric exploration and colonization of the Pacific. Cambridge: Cambridge University Press.

IRWIN, G. J.

1998 The colonisation of the Pacific: Chronological, navigational and social issues. Journal of the Polynesian Society 107(2): 111-144. 
2000 No man is an island: The importance of context in the study of the colonisation of the Pacific islands, in Australian archaeologist: Collected papers in honour of Jim Allen: 393-411, ed. A. Anderson and T. Murray. Canberra: Coombs Academic Publishing, Australian National University.

KIRCH, P. V.

1973 Prehistoric subsistence patterns in the northern Marquesas Islands, French Polynesia. Archaeology and physical anthropology in Oceania 8(1):24-40.

1988 Circumscription theory and sociopolitical evolution in Polynesia. American Behavioral Scientist 31(4) : 416-427.

1991 Chiefship and competitive involution: The Marquesas Islands of eastern Polynesia, in Chiefdoms: Power, economy, and ideology: 119-145, ed. T. Earle. Cambridge: Cambridge University Press.

1994 The wet and the dry: Irrigation and agricultural intensification in Polynesia. Chicago: University of Chicago Press.

1997 The Lapita peoples: Ancestors of the Oceanic world. Oxford: Blackwell.

2000 Pigs, humans, and trophic competition on small Oceanic islands, in Australian archaeologist: Collected papers in honour of Jim Allen: 427-439, ed. A. Anderson and T. Murray. Canberra: Coombs Academic Publishing, Australian National University.

Kirch, P. V., AND D. LepofsKy

1993 Polynesian irrigation: Archaeological and linguistic evidence for origins and development. Asian Perspectives 32:183-204.

Krebs, J. R., and A. Kacelnik

1991 Decision-making, in Behavioural ecology: An evolutionary approach, 3rd ed: 105-136, ed. J. R. Krebs and N. B. Davies. Oxford: Blackwell Scientific.

LEACH, B. F.

2006 Fishing in pre-European New Zealand. Wellington: New Zealand Journal of Archaeology and Archaeofauna.

LEACH, H. M.

1997 The terminology of agricultural origins and food production systems-a horticultural perspective. Antiquity $71: 135-148$.

1999 Intensification in the Pacific. Current Anthropology 40:311-321.

Noli, D., And G. Avery

1988 Protein poisoning and coastal subsistence. Journal of Archaeological Science $15: 395-401$.

Petchey, F. J.

2001 Radiocarbon determinations from the Mulifanua Lapita site, Upolu, Western Samoa. Radiocarbon 43(1):63-68.

Rolett, B. V.

1998 Hanamiai: Prehistoric colonization and cultural change in the Marquesas Islands, East Polynesia. Yale University Publications in Anthropology, No. 81. New Haven: Department of Anthropology and The Peabody Museum, Yale University.

Rush, D.

1989 Effect of changes in protein and calorie intake during pregnancy on the growth of the human fetus, in Effective care in pregnancy and childbirth, vol. 1: Pregnancy: 255-280, ed. I. Chalmers, M. Enkin, and M. Kierse. Oxford: Oxford University Press.

SAND, C.

2000 La datation du premier peuplement de Wallis et Futuna: Contribution à la définition de la chronologie Lapita en Polynésie occidentale. Journal de la Société des Océanistes 111: 165-172.

2003 Trois mille ans de Polynésie à Wallis et Futuna, in Le grand Océan: L'espace et le temps du Pacifique: 87-113, ed. S. Dunis. Geneva: Georg Éditeur, collection Ethnos.

SPETH, J. D.

1989 Early hominid hunting and scavenging: The role of meat as an energy source. Journal of Human Evolution 18:329-343.

1991 a Nutritional constraints and late glacial adaptive transformations: The importance of nonprotein energy sources, in The late glacial in north-west Europe: Human adaptation and environmental change at the end of the Pleistocene: 169-178, ed. N. Barton, A. J. Roberts, and D. A. Roe. CBA Research Report No. 77. London: Council for British Archaeology. 
$1991 \mathrm{~b}$ Protein selection and avoidance strategies of contemporary and ancestral foragers: unresolved issues. Philosophical Transactions of the Royal Society (London) B 334:265-270.

Speth, J. D., and K. A. Spielmann

1983 Energy source, protein metabolism, and hunter-gatherer subsistence strategies. Journal of Anthropological Archaeology 2:1-31.

Spriggs, M. J.

2002 Taro cropping systems in the Southeast Asian-Pacific region: An archaeological update, in Vegeculture in Eastern Asia and Oceania, ed. P. J. Matthews and S. Yoshida. JCAS Symposium Series No. 16. Osaka: National Museum of Ethnology.

SPriggs, M.J.T.

1981 Vegetable Kingdoms: Taro irrigation and Pacific prehistory. Ph.D. diss. Australian National University.

1984 Taro irrigation techniques in the Pacific, in Edible Aroids: 123-135, ed. S. Chandra. Oxford: Clarendon Press.

1990 Why irrigation matters in Pacific Prehistory, in Pacific production systems: Approaches to economic prehistory. Papers from a symposium at the XV Pacific Science Congress, Dunedin, New Zealand, 1983: 174-189, ed. D. E. Yen and J.M.J. Mummery. Occasional Papers in Prehistory, No. 18. Canberra: Department of Prehistory, Research School of Pacific Studies, Australian National Museum.

Sweeny, M., M. Graves, and T. L. Hunt

1993 A reappraisal of evidence for subsistence change at Hane Dune site, Marquesas Island, French Polynesia. Asian Perspectives $32: 225-238$.

YEN, D. E.

1973a Agriculture in Anutan subsistence, in Anuta: A Polynesian outlier in the Solomon Islands: 112-149, ed. D. E. Yen and J. Gordon. Pacific Anthropological Records 21. Honolulu: Bishop Museum.

$1973 b$ The origins of Oceanic agriculture. Archaeology and Physical Anthropology in Oceania 8:6885 .

1990 Environment, agriculture and the colonisation of the Pacific, in Pacific production systems: Approaches to economic prehistory: 231-277, ed. D. E. Yen and J.M.J. Mummery. Papers from a symposium at the XV Pacific Science Congress, Dunedin, New Zealand, 1983. Occasional Papers in Prehistory 18. Canberra: Department of Prehistory, Research School of Pacific Studies, Australian National University.

1993 Pacific subsistence systems and aspects of cultural evolution, in A community of culture: The people and prehistory of the Pacific, ed. M. Spriggs, D. E. Yen, W. Ambrose, R. Jones, A. Thorne, and A. Andrews. Occasional Papers in Prehistory 21. Canberra: Department of Prehistory, Research School of Pacific Studies, Australian National University.

\section{ABSTRACT}

This paper proposes that, on the Marquesan island of Nuku Hiva, wet cultivation of Colocasia taro was important in initial colonization because it was the most energyefficient and fastest-producing crop. In later periods its caloric contribution was eclipsed by breadfruit, but irrigated taro played an important risk-reduction role. KEYwORDs: Agriculture, archaeology, intensification, risk-reduction, irrigation, Polynesia. 